\title{
Relative predation risk for fishes along a subtropical mangrove-seagrass ecotone
}

\author{
Neil Hammerschlag ${ }^{1, *}$, Annie B. Morgan ${ }^{1}$, Joseph E. Serafy ${ }^{1,2}$ \\ ${ }^{1}$ Rosenstiel School of Marine and Atmospheric Science, University of Miami, 4600 Rickenbacker Causeway, Miami, \\ Florida 33149, USA \\ ${ }^{2}$ National Oceanic and Atmospheric Administration, National Marine Fisheries Service, Southeast Fisheries Science Center, \\ 75 Virginia Beach Drive, Miami, Florida 33149, USA
}

\begin{abstract}
Many fishes shelter in mangrove habitats by day and forage mostly in seagrass beds by night. This pattern of diel habitat use has been attributed to a predator avoidance strategy, whereby predation risk is reduced by alternating between the cover afforded by prop-roots during the day and darkness at night. We employed a series of diel tethering experiments in Biscayne Bay (Florida, USA) to empirically examine whether relative predation pressure on fishes is lower at night than during the day and to compare relative predation pressure on fishes at different distances from the mangroveseagrass ecotone. Pinfish Lagodon rhomboides ranging from 10 to $17 \mathrm{~cm}$ in total length were tethered during day and night at 10,50, and $110 \mathrm{~m}$ from the mangrove-seagrass ecotone. Pinfish removal rates at night were twice as high as during the day, which contradicts the idea that darkness provides 'cover' during nocturnal foraging in seagrass. Predation losses were highest nearest the mangrove edge and decreased with increasing distance from shore. Our results agree with those of other tethering studies that marine ecotones, or transition zones between refuges and feeding sites, can be areas of high predation pressure for fishes.
\end{abstract}

KEY WORDS: Predators $\cdot$ Edge effects $\cdot$ Proximity gradient $\cdot$ Shark $\cdot$ Snapper $\cdot$ Porgy $\cdot$ Grunt Resale or republication not permitted without written consent of the publisher

\section{INTRODUCTION}

Seagrass beds and mangroves are widely recognized as nursery habitats for a variety of coastal fishes, especially for species that occupy coral reefs as adults (Adams et al. 2006, Blaber 2007, Nagelkerken et al. 2008). Many fishes shelter in mangrove prop-roots by day, but at night disperse into adjacent seagrass beds to feed (Starck \& Schroeder 1970, Rooker \& Dennis 1991, Nagelkerken et al. 2000). These nocturnal movements are presumed to occur primarily due to high food availability and lowered predation risk at night, with darkness providing 'cover' during foraging; however, this assumption has not been empirically tested in mangrove-seagrass systems. Throughout the literature, fishes such as snappers (Lutjanidae) and grunts (Haemulidae) are cited to forage in seagrass at night, presumably taking advantage of reduced predation risk and increased prey availability as their invertebrate prey emerges from the substrate at night (e.g. Starck \& Davis 1966, Nagelkerken et al. 2000, ValdesMunoz \& Mochek 2001, Unsworth et al. 2007).

Reduced predation pressure in mangrove-seagrass habitats is hypothesized to be among the underlying factors behind the relatively high fish densities found in these habitats (reviewed by Adams et al. 2006, Blaber 2007, Nagelkerken et al. 2008). Commonly cited factors presumed responsible for lower predation risk within and near mangroves include increasing levels of turbidity, shade, and structural complexity, which are thought to provide shelter from predators and decrease predator foraging efficiency (Blaber \& Blaber 1980, Robertson \& Blaber 1992, Laegdsgaard \& Johnson 2001). Closer to the prop-roots, fish fleeing distance to mangrove refuges is reduced and water depths tend to be shallower, which may restrict preda- 
tor access (Shulman 1985, Blaber 2007, Rypel et al. 2007). Most previous studies, which have been primarily diurnal, have consistently reported fish densities to be higher nearest the mangroves compared to offshore (e.g. Jelbart et al. 2007, Newman et al. 2007, Unsworth et al. 2008). However, direct field-based evidence evaluating how predation risk varies spatially in seagrass beds in relation to mangrove proximity is lacking.

Ecotones, or habitat transition zones, are recognized as hunting corridors for predators in a variety of systems (Decamps \& Naiman 1988, Ries \& Sisk 2004). Organisms are likely at highest risk from predation when crossing ecotones between sheltered and feeding patches, due to the high concentration of individuals in refuges and predictability of their foraging movements. For example, off the coast of South Africa, hunting white sharks (Carcharodon carcharias) patrol fur seal (Arctocephalus pusillus pusillus) refuge entry and exit points in attempts to ambush seals as they leave for, and return from, foraging (Martin et al. 2005, Hammerschlag et al. 2006, Martin et al. 2009). Although previous studies in a variety of habitats (e.g. reefs, Shulman 1985) have reported predation pressure to be high near ecotones, or habitat edges, this has not been previously reported in mangroveseagrass habitats and results of most published diurnal fish abundance surveys indicate highest fish densities nearest the mangroves (Jelbart et al. 2007, Newman et al. 2007, Unsworth et al. 2008).

Recently, Hammerschlag \& Serafy (in press) examined nocturnal abundance patterns of fishes in subtropical Biscayne Bay, Florida, USA, a marine system rimmed by mangroves (mostly Rhizophora mangle) that transition into dense seagrass (mostly Thalassia testudinum). They found lower nighttime densities of several late-stage juvenile fishes foraging near the mangrove-seagrass ecotone in comparison to further (up to $120 \mathrm{~m}$ ) offshore. Hammerschlag \& Serafy (in press) hypothesized this fish distribution pattern may reflect avoidance of a predator-rich ecotone, which is consistent with the notion that transition zones between sheltered and feeding patches are high risk areas.

In the present study, we employed a series of tethering experiments in subtropical Biscayne Bay to empirically (1) examine whether relative predation pressure on fishes is lower at night than during the day; and (2) compare relative predation pressure on fishes at different distances from the mangrove-seagrass ecotone. We examined diel and distance patterns of predation pressure by tethering pinfish Lagodon rhomboides ranging from 10 to $17 \mathrm{~cm}$ total length (TL), a length range that corresponds to the size classes of fishes best known to make diel migrations among seagrass and mangrove habitats (Rooker \& Dennis 1991, Nagelkerken et al. 2000).

\section{MATERIALS AND METHODS}

Study site. This study was conducted from July to September 2008 (wet season), along the eastern boundary of southern Biscayne Bay (Florida, USA), along the leeward side of Elliott Key between latitudes $25.43^{\circ}$ and $25.41^{\circ} \mathrm{N}$ (Fig. 1). Sampling was focused along three $120 \mathrm{~m}$ long transects that extended perpendicularly from shore. Previous work at this site (Hammerschlag \& Serafy in press, N. Hammerschlag et al. unpublished) revealed that these transects shared the following characteristics: (1) consistently high seagrass and macroalgae bottom cover (mean \pm $\mathrm{SD}=90 \pm 8.0 \%$, range $=66$ to $96 \%$ ) as well as seagrass blade height $(29 \pm 6 \mathrm{~cm}$, range $=18$ to $44 \mathrm{~cm})$; (2) consistently shallow depths $(97 \pm 14 \mathrm{~cm}$, range $=72$ to $120 \mathrm{~cm}$ ) out to $120 \mathrm{~m}$ from shore; and (3) stable salinity $(37 \pm 1.5$, range $=34$ to 39$)$ and temperature (32 \pm $1.2^{\circ} \mathrm{C}$, range $=29$ to $34^{\circ} \mathrm{C}$ ) due to its close proximity to oceanic waters. Additionally, seine net sampling indicated that fish assemblage composition and structure between transects was very similar (Hammerschlag \& Serafy in press). Consistency in the above characteristics across transects limited the possibility that withinand between-transect variation clouded relationships between relative predation rates and distance from the mangrove shoreline.

Tethering apparatus, design, and pilot studies. Tethering experiments have the potential for simple and higher-order artifacts (sensu Peterson \& Black 1994) that can confound results. Simple artifacts include alterations in tethered-fish behavior and health, or encounters with predators that may result in changes in tethered-fish survivorship. Higher-order artifacts occur when there is an interaction between the tethering technique and treatment, as the effect of tethering on prey vulnerability is assumed to be constant across all treatments. We employed a tethering design aimed at minimizing both types of artifacts.

Pinfish were used as prey because individuals ranging from 10 to $20 \mathrm{~cm}$ TL were readily available from a commercial supplier and because pilot studies indicated that these fish were robust to the tethering process, both physically and behaviorally (see below). The tethering technique we employed was modified from Ellis \& Bell (2004). The gear consisted of (1) a $2 \mathrm{~m}$ long (11.34 kg test) monofilament center line with a $226.8 \mathrm{~g}$ lead weight attached at 1 end and a small, plastic float attached to the other; and (2) a $1 \mathrm{~m}$ long (11.34 kg test) monofilament tether line. Deployment was carried out in 3 steps. First, the center line was positioned by pushing the weight into the sediment, allowing the float to sit at the surface. Second, to secure the tether line to a pinfish, 1 end of the line was threaded through the mouth, out through the 


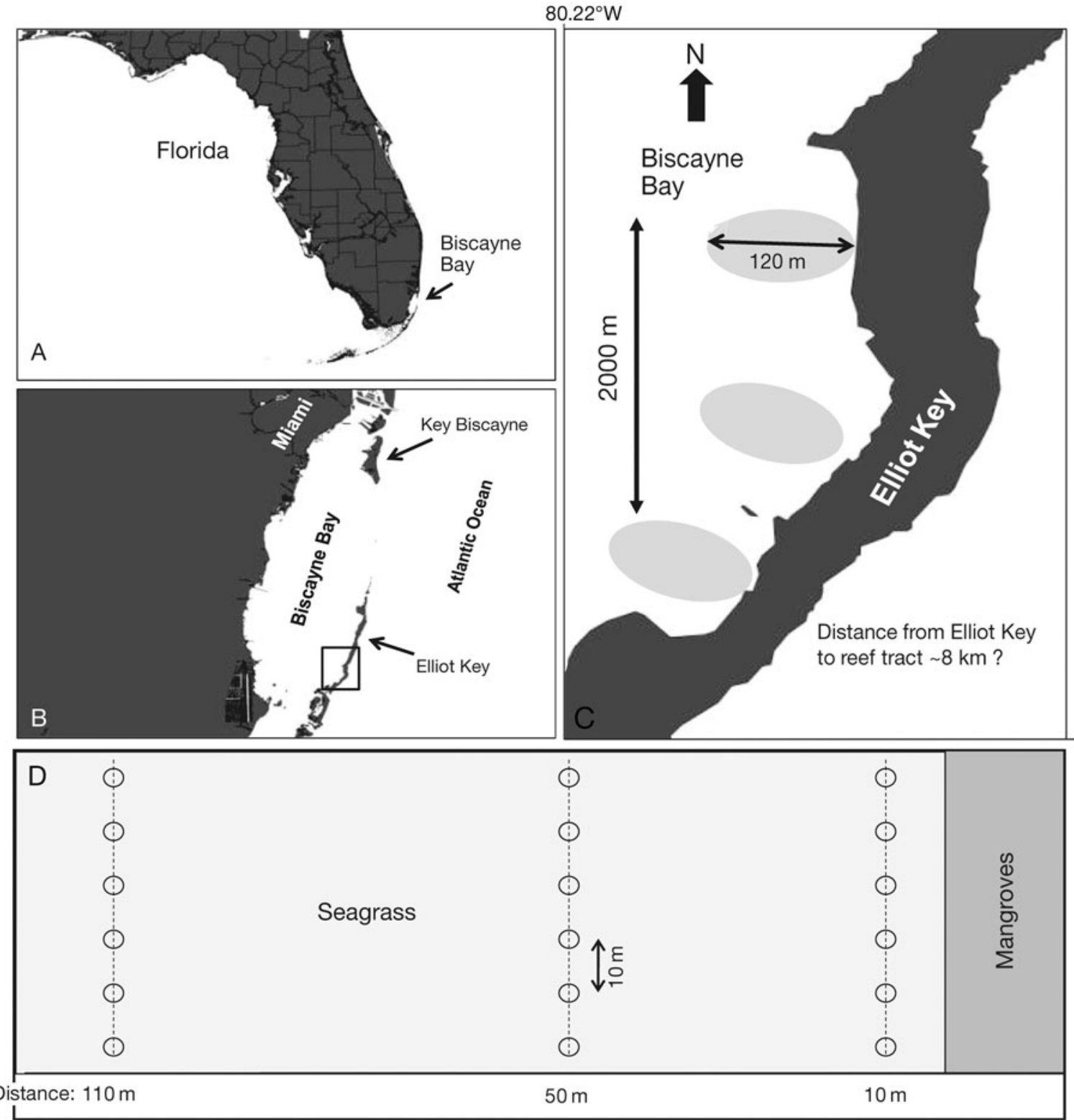

Fig. 1. (A) Florida, depicting location of Biscayne Bay; (B) study area (black square) on leeward side of Elliott Key within Biscayne Bay; (C) location of sampling transects within the study area; (D) birdseye diagram of experimental set-up along the sampling transect. An experimental trial was composed of a group (open circles) of 6 tethered pinfish Lagodon rhomboides deployed at 10, 50 , and $110 \mathrm{~m}$ distances from shore. Within each distance, pinfish were spaced $10 \mathrm{~m}$ apart. Depths were consistently shallow across the transect, averaging $( \pm \mathrm{SD}) 90 \pm 22.3 \mathrm{~cm}$ at $10 \mathrm{~m}$ from shore to $122 \pm 18 \mathrm{~cm}$ at $110 \mathrm{~m}$ from shore

operculum, and was tied to form a loose loop, just forward of the pinfish's snout. Compared to more invasive fish-attachment techniques, which require hooking or suturing the tether line to the fish (Table 1), the method we employed minimizes tissue damage and the release of body fluids, which could inflate detection and/or vulnerability of tethered prey to predators or scavengers. Finally, to secure the tether to the center line, it was connected to the center line using a snap-swivel (0.5 g). This snap-swivel attachment permitted pinfish to move freely in a vertical cylinder, with a $2 \mathrm{~m}$ diameter, from the seagrass to the water surface. To further minimize interactions between our tethering technique and treatment (which commonly occurs in experiments where predation rates are compared between habitats that differ considerably in physical structure), we conducted all experiments such that the treatments (day-night, distance from prop-roots) were compared within a single habitat type (seagrass beds) with consistently high seagrass cover and blade lengths, uniform depths, and stable salinity and temperature regimes. 


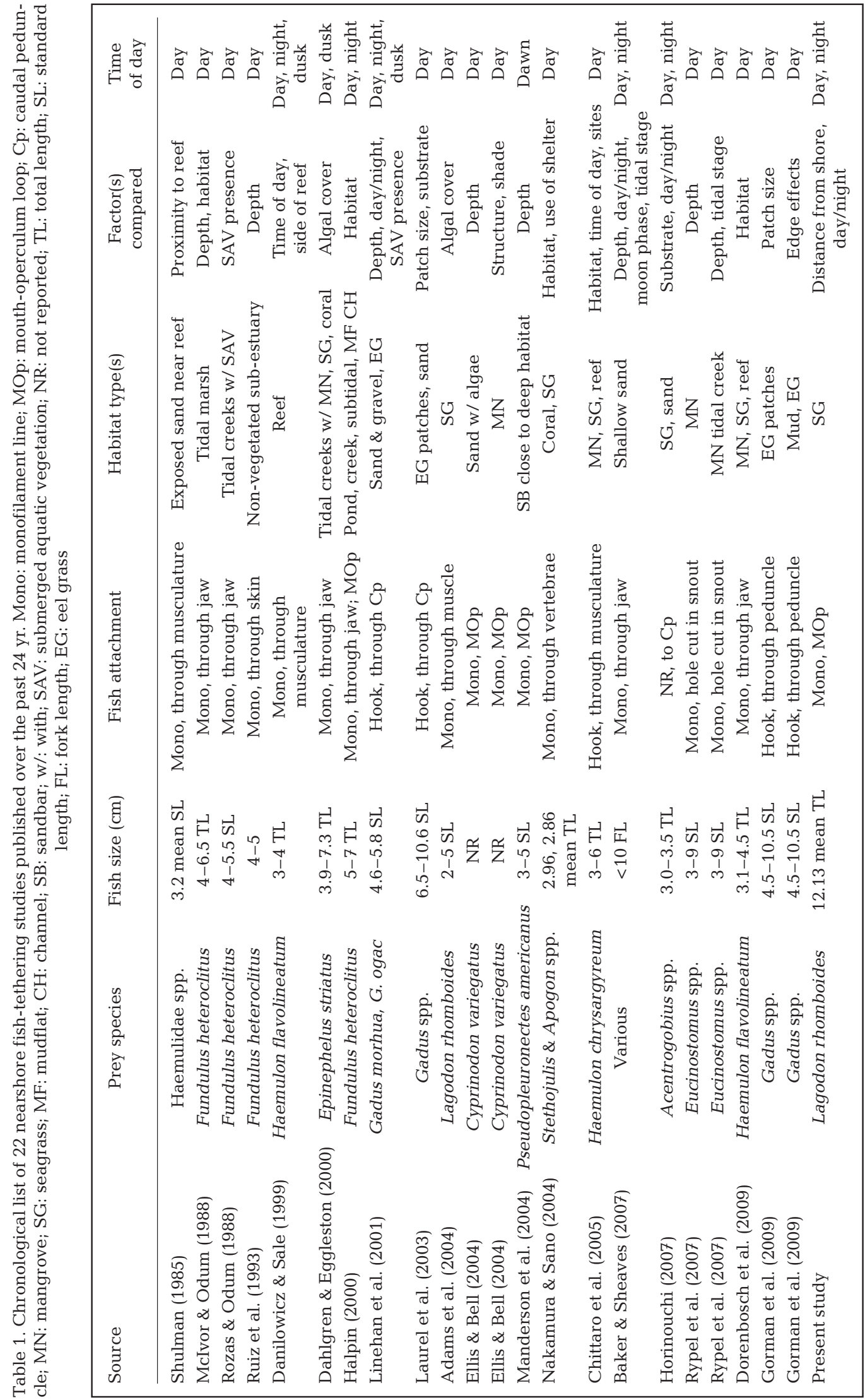


Prior to our study, we made a series of qualitative laboratory and field observations to evaluate our tethering set-up. Tethered pinfish were held in outdoor, fiberglass tanks $(2.3 \times 1.9 \times 0.7 \mathrm{~m})$ and monitored with video cameras for $24 \mathrm{~h}$ for changes in condition or behavior as well as to determine if the fish could break from tethers in the absence of predators. During monitoring, no fish died, exhibited signs of injury, or broke from their tether lines. During field evaluations, tethered fish maintained equilibrium and showed no signs of erratic swimming behavior. Pinfish routinely swam from the substrate, in and out of seagrass, to the water's surface without entanglement. Tethered pinfish were also observed schooling with conspecifics. No obvious tethering artifacts were observed that would prevent comparison of relative predation rates in seagrass beds versus distance from shore or between day and night.

To determine appropriate soak time, we conducted a series of preliminary tethering experiments at 10, 50, and $110 \mathrm{~m}$ distances from shore using soak times of 60 , 90, and $120 \mathrm{~min}$. In total, we conducted 111 pilot tethering deployments: 60 min soak $(\mathrm{n}=36)$, 90 min soak ( $\mathrm{n}=42)$, and 120 min soak $(\mathrm{n}=33)$. We found that 90 and 120 min deployments resulted in uniformly large proportions of tether losses at all distances from shore due to eventual predation, suggesting that these soak times were too long to resolve predation rate differences among the 3 distances from shore. On the other hand, 60 min soak times were optimal among those examined, providing enough time for predation to occur, yet sufficiently brief to resolve distance differences in tether losses.

Tethering experiments. To examine relationships between fish survival and proximity to mangroves, tethered pinfish were deployed at distances of 10, 50, and $110 \mathrm{~m}$ from the mangrove shoreline by day and by night. At deployment, pinfish were measured to the nearest mm TL. An experimental trial was composed of a group of 6 tethered pinfish deployed at each of the 3 distances from shore (Fig. 1D). In each trial, we randomized the sequence in which pinfish were deployed at each distance from shore. At each distance, pinfish were spaced $10 \mathrm{~m}$ apart. All tethers were retrieved after $60 \mathrm{~min}$, with an absence of the pinfish (or presence of a severed fish or a predator on the line) scored as a predation event. All experiments occurred within $2.5 \mathrm{~h}$ of low tide. Daytime tethering began 60 to $90 \mathrm{~min}$ after noon in full daylight; nocturnal tethering began $>30$ min after sunset, in complete darkness. Diel and distance differences in predation loss were assessed using chi-squared analysis (SAS). Throughout, statistical significance was declared at the $\mathrm{p}<0.05$ level.

Qualitative predator identification efforts. Three complementary techniques were used to qualitatively identify potential predators of mangrove-dwelling fishes at our study site. (1) Several piscivores were caught because they swallowed tethered pinfish without breaking the line. At retrieval, these predators were identified and measured for TL. (2) Five tethering experiments (2 during the day and 3 at dusk) were conducted with accompanying underwater video cameras. Underwater video cameras were placed in the seagrass facing the tether and left recording for $60 \mathrm{~min}$; tethering experiments were run as described above. Predators observed preying on tethered pinfish were recorded on videotape and identified, and TL was estimated. (3) Twenty nocturnal gillnet collections were conducted along the 3 transects at our study site. Gillnet gear specifications $(180 \times 3 \mathrm{~m}, 11.8 \mathrm{~cm}$ stretched mesh, weighted) and survey procedures followed those used by Heupel et al. (2006) and Wiley \& Simpfendorfer (2007). This procedure is highly selective for particular nearshore predators, such as juvenile sharks (Heupel et al. 2006, Wiley \& Simpfendorfer 2007). Gill-netted animals were identified, measured for TL, and released.

\section{RESULTS}

Tethering experiments. In total, 234 tethering deployments (60 min each) were conducted (126 during the day and 108 at night) using 10 to $17 \mathrm{~cm}$ TL (mean \pm $\mathrm{SD}=12.13 \pm 1.4 \mathrm{~cm}$ ) pinfish. Of the 234 deployments, $87(37 \%)$ predation events were tallied (i.e. tethered fish were either missing or found severed). Predation rates ranged from $10 \%$ at the farthest distances from shore $(110 \mathrm{~m})$ during the day to nearly $70 \%$ at distances nearest the mangroves $(10 \mathrm{~m})$ at night. During the day, predation losses decreased significantly with increasing distance from shore $(\mathrm{p}<0.009$, Fig. 2a). Similarly, nocturnal predation losses significantly decreased with increasing distance from the proproots ( $p<0.01$, Fig. $2 b$ ). Removal rates were approximately twice as high at night compared to the day $(\mathrm{p}<$ 0.0001).

Qualitative predator identification efforts. We were able to identify the 5 piscivores that were caught on tethers when they swallowed tethered pinfish without breaking the line. During the day, this included 2 gray snapper Lutjanus griseus (30 cm each), 1 great barracuda Sphyraena barracuda $(45 \mathrm{~cm}), 1$ houndfish Tylosurus crocodilus $(87 \mathrm{~cm})$, and 1 nurse shark Ginglymostoma cirratum $(45 \mathrm{~cm})$. No predators were caught on tether lines at night. In the 5 tethering deployments monitored by video, 2 nurse sharks (ca. $100 \mathrm{~cm}$ ) were filmed during the day and 3 juvenile lemon sharks Negaprion brevirostris (ca. $100 \mathrm{~cm}$ each) were observed removing tethered pinfish at dusk. Nocturnal 


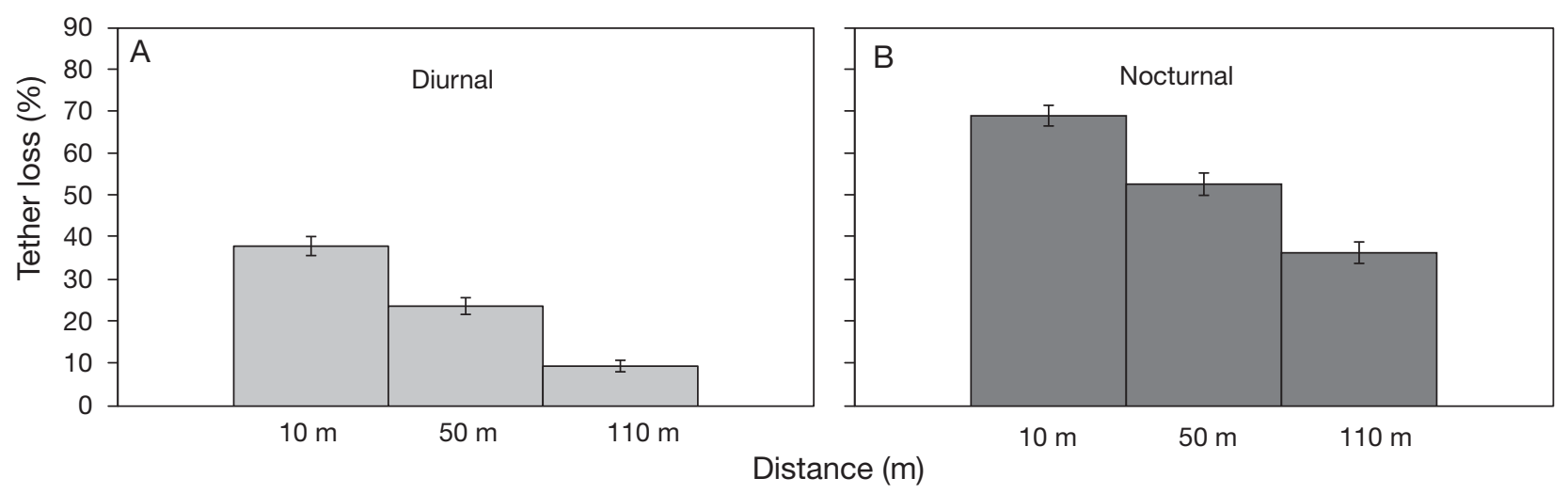

Fig. 2. Lagodon rhomboides. Predation losses (percent predation) of tethered pinfish in relation to mangrove proximity during (A) the day and (B) the night. Error bars indicate $\pm 1 \mathrm{SE}$

gill-netting yielded 6 juvenile lemon sharks, ranging from 74 to $122 \mathrm{~cm}$ TL (mean $\pm \mathrm{SD}=91.2 \pm 17.5 \mathrm{~cm}$ ), and 20 bonnethead sharks Sphyrna tiburo, ranging in size from 68 to $85 \mathrm{~cm}$ TL $(76.4 \pm 4.6 \mathrm{~cm})$. All lemon shark catches were within $60 \mathrm{~m}$ of the mangroves; $60 \%$ were within $40 \mathrm{~m}$ of shore. In contrast, $90 \%$ of bonnethead sharks were caught between 120 and $160 \mathrm{~m}$ from shore.

\section{DISCUSSION}

Reduced predation risk at night is commonly invoked as one of the main reasons for nocturnal movement and feeding in seagrass beds by fishes that shelter in mangrove habitats by day (e.g. Starck \& Davis 1966, Nagelkerken et al. 2000, Valdes-Munoz \& Mochek 2001). Reduced predation pressure in mangroveseagrass habitats is hypothesized to be among the underlying factors behind the relatively high fish densities found in these habitats (reviewed by Blaber 2007, Nagelkerken et al. 2008). Despite an increasing number of empirical studies from a variety of systems showing that predation pressure is high near habitat edges (Decamps \& Naiman 1988, Ries \& Sisk 2004), this has not been previously reported in mangrove-seagrass habitats and is at odds with results from most published fish abundance surveys that reveal highest fish densities near, as opposed to far from, the mangroves (e.g. Jelbart et al. 2007, Newman et al. 2007). In this study, we found that predation rates on 10 to $17 \mathrm{~cm} \mathrm{TL}$ pinfish were nearly twice as high at night compared to the day, which is inconsistent with the notion that darkness provides 'cover' during foraging bouts into seagrass beds. We found that fish mortality due to predation was highest nearest the mangrove edge, decreasing with increasing distance from shore. This finding is shared by a growing number of fish tethering studies in and around ecotones (see below).
Our results are comparable to those reported from a coral reef in the US Virgin Islands, where predation rates on tethered juvenile grunts were higher at night than in the day (Danilowicz \& Sale 1999). Our data suggest that nocturnal foraging migrations of mangrove-associated fishes in seagrass beds are driven primarily by enhanced food abundance at night and that fish foraging during these times incur the cost of enhanced predation risk. Although this tethering study is the first to investigate patterns in predation pressure across a mangrove-seagrass distance gradient, our results are consistent with other fish tethering studies in different nearshore environments. For example, working in Newfoundland, Canada, Gorman et al. (2009) found that predation on age-0 Atlantic cod (Gadus spp.) was more than twice as high at the seagrass-mud boundary compared to just $10 \mathrm{~m}$ away. Similarly, working in the US Virgin Islands, Shulman (1985) found that predation of small grunt species was 1.4 times higher at the coral reef edge, compared to just $20 \mathrm{~m}$ away.

The results of our study support the hypothesis proposed by Hammerschlag \& Serafy (in press) that the mangrove-seagrass interface and its immediate surroundings may be high-risk areas for fishes migrating to forage, especially at dusk or night when predators may have a visual advantage (Munz \& McFarland 1973). This is further supported by studies from Bahamian waters documenting that lemon sharks, one of the main predators identified in our study, tend to focus search efforts near the mangrove shoreline (Morrissey \& Gruber 1993, Franks 2007). Recent acoustic tracking of gray snapper in Biscayne Bay (Luo et al. 2009) also indicates that the snappers may avoid foraging near the mangroves at night. At sunset, gray snapper migrate rapidly out of the mangroves in a synchronized fashion and do not forage in seagrass nearest the mangroves, but rather move as much as $500 \mathrm{~m}$ offshore, before returning to the same mangrove proproots the following morning (Luo et al. 2009). 
There have been several recent efforts to identify and describe general patterns of predation pressure to fishes in nearshore environments using tethering experiments (Table 1). Sizes of fishes used in different tethering experiments have ranged from $<3 \mathrm{~cm}$ TL (Nakamura \& Sano 2004) to a maximum of about $10 \mathrm{~cm}$ TL (Laurel et al. 2003, Gorman et al. 2009). However, fishes $>10 \mathrm{~cm}$ TL correspond to size classes best known to make diel mangrove-seagrass migrations (e.g. Rooker \& Dennis 1991, Nagelkerken et al. 2000). Thus, caution should be exercised when generalizing about patterns of predation risk for fishes that make diel mangrove-seagrass migrations based on previous studies that used fish $<10 \mathrm{~cm}$ TL.

Predation risk can be decomposed into 2 components: the probability that a prey encounters a predator and the probability of death as a result of that encounter (Lima \& Dill 1990, Hugie \& Dill 1994). Probability of death given an encounter is often mediated by differences in habitat characteristics (e.g. amount of physical structure), escape ability, and their interaction (Hugie \& Dill 1994, Heithaus et al. 2009). Tethering experiments only measure relative predator encounter rates. Thus, we must consider that the probability of fish escaping back into the mangroves given an encounter with a predator may be higher at the mangrove fringe compared to just several meters away. However, this scenario is dependent on fish being able to detect predators patrolling the mangroves, which is likely hindered at night, when predators may have a visual advantage (Munz \& McFarland 1973). Pending further studies on the fleeing and predator-detection capabilities of vulnerable fishes, we conclude that at our site, as fish begin to migrate away to feed in adjacent seagrass beds, they are likely at high risk nearest shore as compared to further away.

We were able to determine the identity of a number of potential predators at our study site. A variety of large piscivores removed tethered fish during the day, including great barracuda, gray snapper, and nurse sharks. These species are known predators of small fishes in back-reef habitats (de Sylva 1963, Starck \& Schroeder 1970, Castro 2000). During dusk, only juvenile lemon sharks were found removing pinfish. In our nocturnal gillnet surveys, juvenile lemon and bonnethead sharks were caught. Most lemon sharks were captured close to shore, while most bonnethead sharks were caught offshore (>120 m). Lemon sharks are piscivorous (Newman 2003), while bonnethead sharks are omnivorous, feeding mainly on crustaceans (Bethea et al. 2007). Based on our preliminary results, and those reported from other nearby studies (e.g. Morrissey \& Gruber 1993, Franks 2007), we hypothesize that juvenile lemon sharks patrolling the shoreline at night are primarily responsible for the elevated predation rates found closest to the mangroves at night. However, future studies are needed to adequately identify the full suite of predators in our study domain and reveal diel differences, if any.

Although in this study we attempted to minimize tethering artifacts, it is possible that some arose due to inherent limitations of the tethering approach. For example, a tethered pinfish may have struggled on the line, unduly attracting a predator that would otherwise not have normally detected, pursued, or been able to capture a pinfish (Adams et al. 2004). However, because experiments were conducted using the same procedure in a single habitat type, we doubt that such artifacts would have varied with distance from shore or by time of day, thus preventing comparisons of relative predation rates in seagrass beds versus distance or between day and night.

Our sampling design and findings may not be directly transferable to all mangrove-seagrass systems. For instance, in other systems, our sampling regime (with closest sampling distance of $10 \mathrm{~m}$ to shore) may be too small or large to reveal the nature of predation pressure-mangrove proximity relationships, if they exist. Additionally, our nocturnal results are based on sampling that took place in complete darkness, but still relatively early in the night. Thus, it is possible that predation pressure during this period may not be the same as much later in the night, or just before dawn. Likewise, it is possible that predation pressure varies over the course of the day; therefore, we recommend that future work investigate if and how predation pressure changes in relation to mangrove proximity over the entire $24 \mathrm{~h}$ cycle. Until then, however, our results support the idea that the mangrove-seagrass ecotone is likely a high-risk area, especially for fish that conduct diel migrations between mangroves and seagrass beds.

Acknowledgements. Funding for this work was provided by the Herbert W. Hoover Foundation, Batchelor Foundation Inc., NOAA Living Marine Resources Cooperative Science Center, National Park Service (Biscayne National Park, BNP), SeaStar Foundation, Save The Blue, YSI Inc., the Rosenstiel School of Marine and Atmospheric Science and the University of Miami's South Florida Student Shark Program (SFSSP), now the RJ Dunlap Marine Conservation Program. As part of the educational component of this project, several hundreds of high school and undergraduate students were involved in field data collection, laboratory processing and data organization. We are indebted to the technical support of all Program participants, primarily D. Ovando, A. Matulik, D. Lazarre, A. Krajca, L. Winn, E. Overstreet, L. Rock, A. Griefen, M. Fast, L. Glade, K. Titley, D. Washington, and J. Allen. Special thanks to M. Heithaus, D. Lirman, L. Brand, T. Kellison, G. Thomas, D. Die, C. M. Hammerschlag, L. Yeager, L. Hoover, and R. Mann. For logistical support, thanks to P. B. Teare, G. Myers, M. Giganti, M. Lewis, E. Alvear, R. Curry, and H. M. Tritt. Thanks to also the anonymous reviewers whose 
comments helped strengthen the manuscript. This work was conducted under BNP Permit no. BISC-2008-SCI-0005 and the University of Miami Institutional Animal Care and Use Committee (IACUC) Protocol no. 05-244 renewal 02.

\section{LITERATURE CITED}

Adams AJ, Locascio JV, Robbins BD (2004) Microhabitat use by a post-settlement stage estuarine fish: evidence from relative abundance and predation among habitats. J Exp Mar Biol Ecol 299:17-33

Adams AJ, Dahlgren CP, Kellison GT, Kendall MS and others (2006) Nursery function of tropical back-reef systems. Mar Ecol Prog Ser 318:287-301

Baker R, Sheaves M (2007) Shallow-water refuge paradigm: conflicting evidence from tethering experiments in a tropical estuary. Mar Ecol Prog Ser 349:13-22

Bethea DM, Hale L, Carlson JK, Cortes E, Manire CA, Gelsleichter J (2007) Geographic and ontogenetic variation in the diet and daily ration of the bonnethead shark, Sphyrna tiburo, from the eastern Gulf of Mexico. Mar Biol 152: 1009-1020

Blaber SJM (2007) Mangroves and fishes: issues of diversity, dependence, and dogma. Bull Mar Sci 80:457-472

Blaber SJM, Blaber TG (1980) Factors affecting the distribution of juvenile estuarine and inshore fish. J Fish Biol 17: $143-162$

Castro JI (2000) The biology of the nurse shark, Ginglymostoma cirratum, off the Florida east coast and the Bahama Islands. Environ Biol Fishes 58:1-22

> Chittaro PM, Usseglio P, Sale P (2005) Variation in fish density, assemblage composition and relative rates of predation among mangrove, seagrass and coral reef habitats. Environ Biol Fishes 72:175-187

Dahlgren CP, Eggleston DB (2000) Ecological processes underlying ontogenetic habitat shifts in a coral reef fish. Ecology 81:2227-2240

> Danilowicz BS, Sale PF (1999) Relative intensity of predation on the French grunt, Haemulon flavolineatum, during diurnal, dusk, and nocturnal periods on a coral reef. Mar Biol 133:337-343

de Sylva D (1963) Systematics and life history of the great barracuda Sphyraena barracuda (Walbaum), Vol 1. Institute of Marine Science, University of Miami, Coral Gables, FL

Decamps H, Naiman RJ (1988) Towards an ecotone perspective. In: Naiman RJ, Decamps H (eds) Symposium of the Man and Biosphere Program (MaB-5). UNESCO, Sopron, p 1-5

Dorenbosch M, Grol MGG, de Groene A, Van der Velde G, Nagelkerken I (2009) Piscivore assemblages and predation pressure affect relative safety of some back-reef habitats for juvenile fish in a Caribbean bay. Mar Ecol Prog Ser 379:181-196

Ellis WL, Bell SS (2004) Conditional use of mangrove habitats by fishes: depth as a cue to avoid predators. Estuaries 27 : 966-976

Franks B (2007) The spatial ecology and resource selection of juvenile lemon sharks (Negaprion brevirostris) in their primary nursery areas. PhD thesis, Drexel University, Philadelphia, PA

> Gorman AM, Gregory RS, Schneider DC (2009) Eelgrass patch size and proximity to the patch edge affect predation risk of recently settled age 0 cod (Gadus). J Exp Mar Biol Ecol 371:1-9

Halpin PM (2000) Habitat use by an intertidal salt-marsh fish: trade-offs between predation and growth. Mar Ecol Prog Ser 198:203-214
Hammerschlag N, Serafy J (in press) Nocturnal fish utilization of a subtropical mangrove-seagrass ecotone. PSZN I: Mar Ecol doi:10.1111/j.1439-0485.2009.00337.x

> Hammerschlag N, Martin RA, Fallows C (2006) Effects of environmental conditions on predator-prey interactions between white sharks (Carcharodon carcharias) and Cape fur seals (Arctocephalus pusillus pusillus) at Seal Island, South Africa. Environ Biol Fishes 76:341-350

Heithaus MR, Wirsing AJ, Burkholder D, Thomson J, Dill LM (2009) Towards a predictive framework for predator risk effects: the interaction of landscape features and prey escape tactics. J Anim Ecol 78:556-562

Heupel MR, Simpfendorfer CA, Collins AB, Tyminski JP (2006) Residency and movement patterns of bonnethead sharks, Sphyrna tiburo, in a large Florida estuary. Environ Biol Fishes 76:47-67

Horinouchi M (2007) Distribution patterns of benthic juvenile gobies in and around seagrass habitats: effectiveness of seagrass shelter against predators. Estuar Coast Shelf Sci 72:657-664

Hugie DM, Dill LM (1994) Fish and game - a game theoretical approach to habitat selection by predators and prey. J Fish Biol 45 (Suppl A):151-169

Jelbart JE, Ross PM, Connolly RM (2007) Fish assemblages in seagrass beds are influenced by the proximity of mangrove forests. Mar Biol 150:993-1002

> Laegdsgaard P, Johnson C (2001) Why do juvenile fish utilise mangrove habitats? J Exp Mar Biol Ecol 257:229-253

Laurel BJ, Gregory RS, Brown JA (2003) Predator distribution and habitat patch area determine predation rates on age0 juvenile cod Gadus spp. Mar Ecol Prog Ser 251:245-254

> Lima SL, Dill LM (1990) Behavioral decisions made under the risk of predation - a review and prospectus. Can J Zool 68:619-640

> Linehan JE, Gregory RS, Schneider DC (2001) Predation risk of age-0 cod (Gadus) relative to depth and substrate in coastal waters. J Exp Mar Biol Ecol 263:25-44

> Luo J, Serafy JE, Sponaugle S, Teare PB, Kieckbusch D (2009) Movement of gray snapper Lutjanus griseus among subtropical seagrass, mangrove, and coral reef habitats. Mar Ecol Prog Ser 380:255-269

Manderson JP, Pessutti J, Hilbert JG, Juanes F (2004) Shallow water predation risk for a juvenile flatfish (winter flounder; Pseudopleuronectes americanus, Walbaum) in a northwest Atlantic estuary. J Exp Mar Biol Ecol 304: $137-157$

Martin RA, Hammerschlag N, Collier RS, Fallows C (2005) Predatory behaviour of white sharks (Carcharodon carcharias) at Seal Island, South Africa. J Mar Biol Assoc UK 85:1121-1135

Martin RA, Rossmo KD, Hammerschlag N (2009) Geographic profiling and hunting patterns of white sharks. J Zool (Lond) 279:111-118

McIvor CC, Odum WE (1988) Predation risk, and microhabitat selection in a marsh fish assemblage. Ecology 69: 1341-1351

Morrissey JF, Gruber SH (1993) Home range of juvenile lemon sharks, Negaprion brevirostris. Copeia 1993:425-434

> Munz FW, McFarland WN (1973) Significance of spectral position in rhodopsins of tropical marine fishes. Vision Res 13:1829-1874

Nagelkerken I, Dorenbosch M, Verberk WCEP, de la Morinière EC, van der Velde G (2000) Day-night shifts of fishes between shallow-water biotopes of a Caribbean bay, with emphasis on the nocturnal feeding of Haemulidae and Lutjanidae. Mar Ecol Prog Ser 194:55-64

Nagelkerken I, Blaber SJM, Bouillon S, Green P and others 
(2008) The habitat function of mangroves for terrestrial and marine fauna: a review. Aquat Bot 89:155-185

Nakamura Y, Sano M (2004) Is there really lower predation risk for juvenile fishes in a seagrass bed compared with an adjacent coral area? Bull Mar Sci 74:477-482

Newman SP (2003) Spatial and temporal variation in diet and prey preference of nursery-bound juvenile lemon sharks (Negaprion brevirostris) at Bimini, Bahamas. PhD thesis, University of Plymouth

Newman SP, Handy RD, Gruber SH (2007) Spatial and temporal variations in mangrove and seagrass faunal communities at Bimini, Bahamas. Bull Mar Sci 80:529-553

Peterson CH, Black R (1994) An experimentalist's challenge: when artifacts of intervention interact with treatments. Mar Ecol Prog Ser 111:289-297

Ries L, Sisk TD (2004) A predictive model of edge effects. Ecology 85:2917-2926

Robertson AI, Blaber SJM (1992) Plankton, epibenthos and fish communities. In: Robertson AI, Alongi DM (eds) Tropical mangrove ecosystems. American Geophysical Union, Washington, DC, p 173-224

Rooker JR, Dennis GD (1991) Diel, lunar and seasonalchanges in a mangrove fish assemblage off southwestern Puerto Rico. Bull Mar Sci 49:684-698

Rozas LP, Odum WE (1988) Occupation of submerged aquatic vegetation by fishes: testing the roles of food and refuge. Oecologia 77:101-106

Ruiz GM, Hines AH, Posey MH (1993) Shallow water as refuge habitat for fish and crustaceans in non-vegetated

Editorial responsibility: Thomas Minello,

Galveston, Texas, USA estuaries: an example from Chesapeake Bay. Mar Ecol Prog Ser 99:1-16

Rypel AL, Layman CA, Arrington DA (2007) Water depth modifies relative predation risk for a motile fish taxon in Bahamian tidal creeks. Estuar Coast 30:518-525

Shulman MJ (1985) Recruitment of coral-reef fishes - effects of distribution of predators and shelter. Ecology 66: 1056-1066

Starck W, Davis W (1966) Night habits of fishes of Alligator Reef, Florida. Icthyologica 38:313-356

Starck W, Schroeder R (1970) Investigation on the gray snapper, Lutjanus griseus, Vol 10. University of Miami Press, Coral Gables, FL

- Unsworth RKF, Wylie E, Smith DJ, Bell JJ (2007) Diel trophic structuring of seagrass bed fish assemblages in the Wakatobi Marine National Park, Indonesia. Estuar Coast Shelf Sci 72:81-88

Unsworth RKF, Salinas De Leon P, Garrard SL, Jompa J, Smith DJ, Bell JJ (2008) High connectivity of Indo-Pacific seagrass fish assemblages with mangrove and coral reef habitats. Mar Ecol Prog Ser 353:213-224

Valdes-Munoz E, Mochek AD (2001) Behavior of marine fishes of the Cuban shelf. In: Claro R, Lindeman KC, Parenti LR (eds) Ecology of the marine fishes of Cuba. Smithsonian Institution Press, Washington, DC, p 58-72

Wiley TR, Simpfendorfer CA (2007) The ecology of elasmobranchs occurring in the Everglades National Park, Florida: implications for conservation and management. Bull Mar Sci 80:171-189

Submitted: July 30, 2009; Accepted: December 2, 2009 Proofs received from author(s): February 10, 2010 